\title{
A RARE EUROPEAN ENDEMIC MOSS GENUS ARVERNELLA IS DISCOVERED IN SAKHALIN, RUSSIAN FAR EAST, WHERE IT IS ALSO RARE
}

\section{РЕДКИЙ ЭНДЕМИЧНЫЙ ДЛЯ ЕВРОПЫ РОД ARVERNELLA (ВRYOРНҮТА) НАЙДЕН НА САХАЛИНЕ, РОССИЙСКИЙ ДАЛЬНИЙ ВОСТОК, ГДЕ ОН ТАКЖЕ РЕДОК}

\author{
Michael S. IGNATOV ${ }^{1,2}$, ElENA A. IGNATOVA ${ }^{2} \&$ OXANA I. KUZNETSOVA $^{1}$ \\ МИХАИЛ С. ИГНАТОВ ${ }^{1,2}$, ЕЛЕНА А. ИГНАТОВА ${ }^{2}$, ОКСАНА И. КУЗНЕЦОВА $^{1}$
}

Abstract

\begin{abstract}
A molecular phylogenetic analysis revealed that a tiny Amblystegiaceae plant from Sakhalin in the Russian Far East is most closely related to the recently described European endemic genus and species Arvernella microclada. This species is one of the smallest pleurocarpous mosses and it remains known only from a limited area in France, $9000 \mathrm{~km}$ from Sakhalin. Sakhalin plant differs from European in longer leaf costa and almost smooth laminal cells versus distinctly prorate in A. microclada, in addition to genetic differences. An equally small East Asian Platydictya fauriei, known from Japan and Corea, differs from the Sakhalin plant in its narrow laminal cells (4-6:1 vs. 2.0-2.5:1). Thus, this Sakhalin plant is described as a new species, Arvernella pisarenkoi Ignatov \& Ignatova.
\end{abstract}

Резюме

В результате молекулярно-филогенетического анализа выявлено, что очень мелкое растение из семейства Amblystegiaceae, собранное на о. Сахалин на российском Дальнем Востоке, наиболее близко к недавно описанному из Европы эндемичному роду и виду Arvernella microclada. К этому виду относится один из самых мелких бокоплодных мхов, известный только из очень ограниченного района во Франции, в 9000 км от Сахалина. Сахалинское растение отличается от европейского вида более сильной жилкой, а также клетками листа гладкими или с едва выступающими углами, тогда как у A. microcalda углы клеток выступают сильно. Столь же мелкие растения характерны для другого восточноазиатского вида, Platydictya fauriei, известного из Японии и Кореи, но он отличается от сахалинского растения более узкими клетками пластинки листа (4-6:1 против 2.0-2.5:1). Таким образом, растение с Сахалина описано как новый вид, Arvernella pisarenkoi Ignatov \& Ignatova.

KEYWORDS: mosses, ITS, $a t p \mathrm{~B}-r b c \mathrm{~L}$, new species, East Asia

\section{INTRODUCTION}

Molecular phylogenetic studies proved their usefulness for improving the systematics at family and genera levels (Goffinet et al., 2009; Frey \& Stech, 2009), and in hundreds of cases at the species level. Among the families especially strongly affected by such changes are the Amblystegiaceae. The definition of this family is vague, and in keys to families in handbooks of 20th Century they were simply keyed out as hygrophytic species versus mesophytic Brachytheciaceae. Molecular studies resulted in severe splitting of the Amblystegiaceae (Vanderpoorten et al., 2002; Ignatov et al., 2007), as well as of most of its genera. For Europe, the checklist of Corley et al. (1981) has different generic positions of many species than in the recent checklist of European mosses (Hodgetts et al., 2020) for some genera, as follows (number of species in 1981 / both / in 2020): Hygrohypnum
(13 / 2 / 2), Campylium (7 / 1 / 5), Amblystegium (11 / 1 / 1), and Drepanocladus (15/4/11).

Among the most outstanding novelties in the European Amblystegiaceae was the description of a new genus endemic for Europe (Hugonnot \& Hedenäs, 2015) from France, i.e. from a supposedly very well studied part of Europe (Boulay, 1884; Husnot, 1884-1894). This is Arvernella microclada Hugonnot \& Hedenäs, a very small plant, superficially somewhat similar to Serpoleskea confervoides, although phylogenetically related to a very different genus Campylophyllum (Kučera et al., 2019).

In the course of the revision of the Amblystegiaceae for the Moss flora of Russia, we undertook sequencing of a number of specimens from the Russian Far East, and one of them from Sakhalin Island appeared to be quite similar to the French Arvernella microclada, as discussed below.

\footnotetext{
1 - Tsitsin Main Botanical Garden, Russian Academy of Sciences, Botanicheskaya Str., 4, Moscow 127276 Russia; e-mail: misha ignatov@list.ru, ORCID (MI): 0000-0001-6096-6315; (OK): 0000-0002-5513-1329

2 - Lomonosov Moscow State University, Faculty of Biology, Plant Ecology and Geography Dept., Leninskie Gory Str. 1-12, Moscow 119234 Russia; ORCID (EI): 0000-0001-6287-5660
} 


\section{MATERIAL AND METHODS \\ Sequence aquiring}

The laboratory protocol and sequencing were essentially the same as in our previous moss studies, described in detail by, e.g., Gardiner et al. (2005).

\section{Molecular analysis}

After preliminary result, i.e. when ITS sequence from Sakhalin specimen by BLAST search appeared to be closest to Arvernella, the dataset was compiled to include also taxa close to Arvernella by BLAST.

In addition to the nuclear ITS, the plastid $a t p \mathrm{~B}-r b c \mathrm{~L}$ spacer was included, as sequences of this marker are available in GenBank for French specimens of Arvernella microclada. As the sequences for these two DNA regions were incongruent, two datasets were built for separate analyses, without an attempt to do a concatenated tree. Newly obtained sequence data are shown in Table 1.

Outgroups were chosen from the family Pylaisiaceae, which is the family closest to the Amblystegiaceae (Huttunen et al., 2012; Kučera et al., 2019). The more remotely related Leucodon was added to plastid dataset, while ITS for this genus is too different for confident alignment.

Sequences were aligned using MAFFT v. 7.402 (Katoh \& Standley, 2013) with standard settings.

Bayesian analyses were performed in MrBayes 3.2.6 (Ronquist et al., 2012), with 10000000 generations, and the chain temperature 0.02 in all analyses. Convergence of each analysis was evaluated using Tracer1.4.1 (Rambaut \& Drummond, 2007). Consensus trees were

Fig. 1. Bayesian tree of the Amblystegiaceae based on nuclear ITS sequences. Posterior probabilities and / MP bootstrap supports are shown at branches.

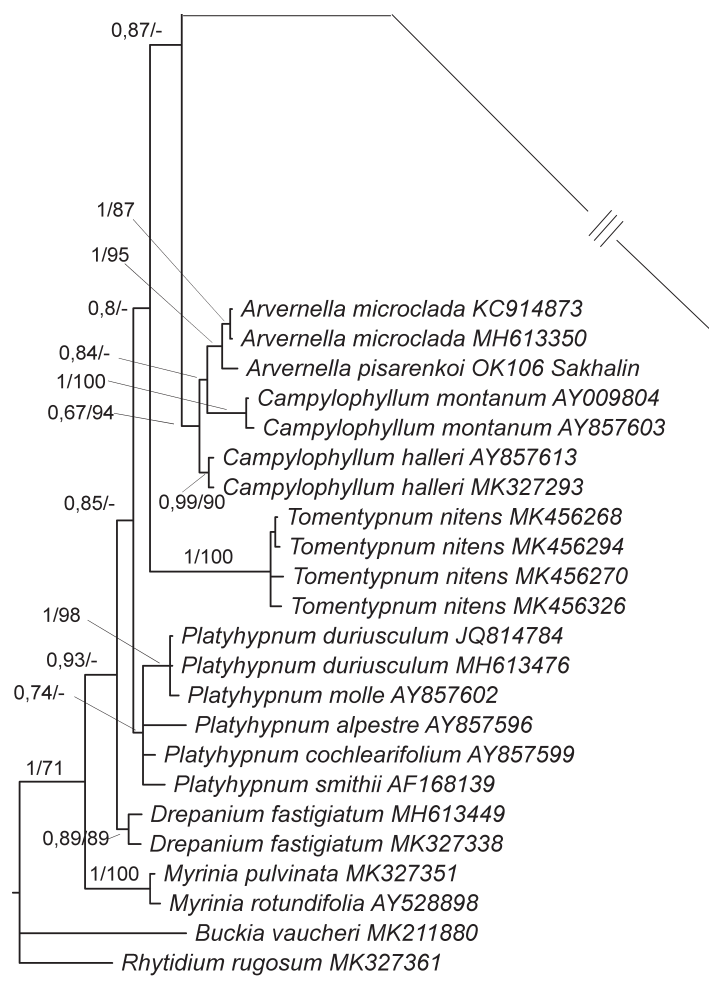

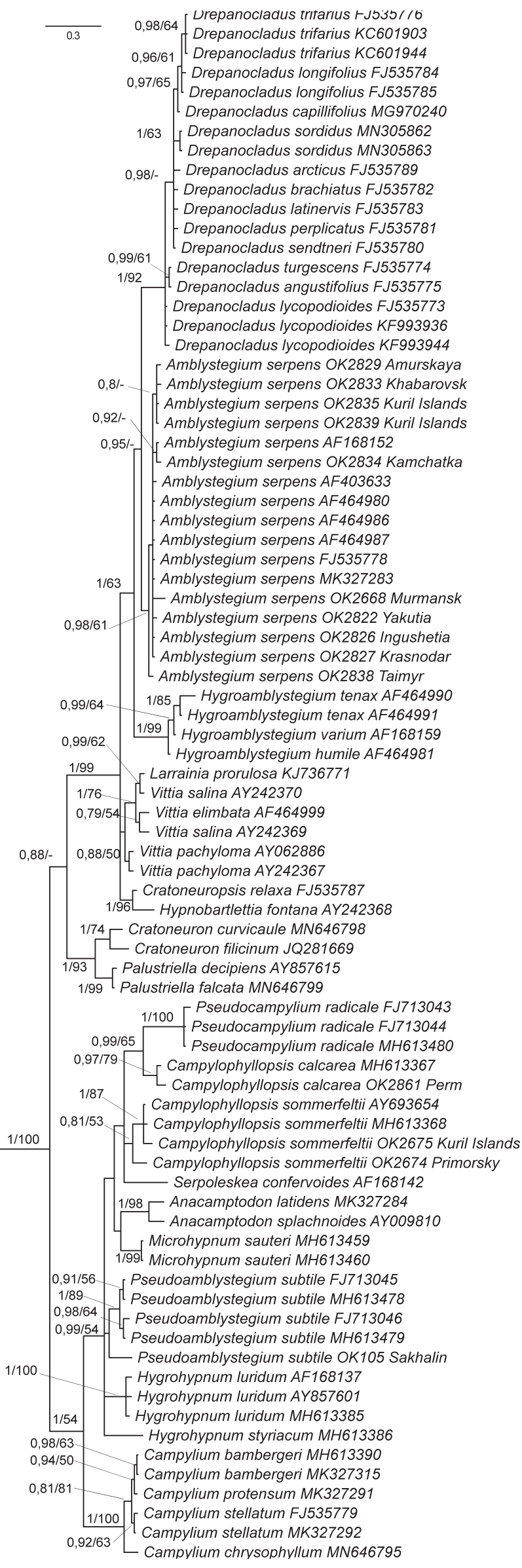




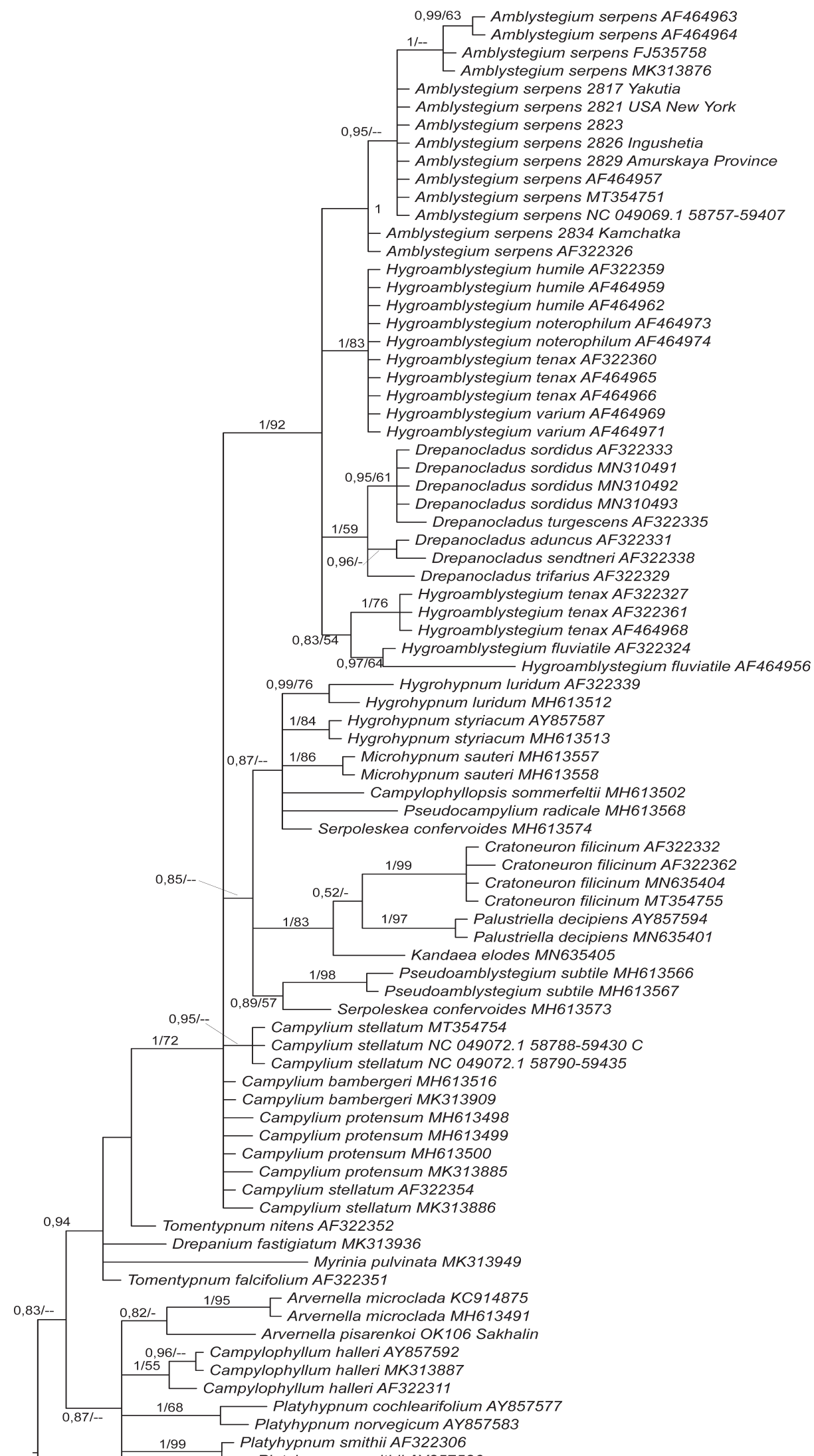

Fig. 2. Bayesian tree of the Amblystegiaceae based on nuclear $a t p \mathrm{~B}-r b c \mathrm{~L}$ sequences. Posterior probabilities and / MP bootstrap supports are shown at branches. 
Table 1. Newly obtained sequences, with specimen vouchers and GenBank accessions.

\begin{tabular}{|c|c|c|c|c|c|}
\hline Species & Isolate & Region & Voucher & ITS & $a t p \mathrm{~B}-r b c \mathrm{~L}$ \\
\hline Amblystegium serpens & OK2668 & Russia, Murmansk & Kozhin M-M-717 MW9078005 & MZ417375 & \\
\hline A. serpens & OK 2822 & Russia, Yakutia & Ignatov \& Ignatova 16-278 MHA9021813 & MZ417377 & \\
\hline A. serpens & OK 2826 & Russia, Ingushetia & Ignatov et al. 18-900 MHA9020899 & MZ417378 & MZ447835 \\
\hline A. serpens & OK2827 & Russia, Krasnodar & Ignatov \& Ignatova 05-330 MHA9000834 & MZ417379 & \\
\hline A. serpens & OK2829 & Russia, Amurskaya Province & Bezgodov 20.VI.2011 \#365 MHA9000875 & MZ417380 & MZ447836 \\
\hline A. serpens & OK2833 & Russia, Khabarovsk, Botchi & Ignatov \& Ignatova 13-685 MHA9000900 & MZ417381 & \\
\hline A. serpens & OK2834 & Russia, Kamchatka & Fedosov 10-3-1085 MW9001219 & MZ417382 & MZ447837 \\
\hline A. serpens & OK 2835 & Russia, Kuril Is., Shikotan & Bakalin K-57-6-07 (MW9001204) & MZ417383 & \\
\hline A. serpens & OK 2838 & Russia, Taimyr, Anabar & Fedosov 11-1177 MW9001193 & MZ417384 & \\
\hline A. serpens & OK2839 & Russia, Kuril Is., Kunashir & Ignatov 06-4106 MHA9000859 & MZ4 & \\
\hline A. serpens & OK2817 & Russia, Yakutia & Ignatov \& Ignatova 15-110 MHA9000910 & & MZ447832 \\
\hline A. serpens & OK2821 & USA, New York & Ignatov 8 Sept 1989 MHA9050247 & & MZ447833 \\
\hline A. serpens & OK2823 & Yakutia, Tirekhyyakh & Ignatov \& Ignatova 18-2932 MHA9029060 & & MZ447834 \\
\hline Arvernella pisarenkoi & $i \mathrm{OK} 106$ & Russia, Sakhalin & Pisarenko op03738 MHA & MZ417374 & MZ447838 \\
\hline \multicolumn{6}{|l|}{ Campylophyllopsis } \\
\hline calcarea & OK2861 & Russia, Perm Province & Bezgodov 16.VI.2017 \#220 MHA9048370 & MZ4 & \\
\hline C. sommerfeltii & OK 2674 & Russia, Primorsky Territory & Ignatov et al. 06-3371 MW9027430 & MZ417376 & \\
\hline C. sommerfeltii & OK2675 & Russia, Kuril Is., Shikotan & Bakalin K-46-5-07 (MW9027429) & MZ417387 & \\
\hline \multicolumn{6}{|l|}{ Pseudoamblystegium } \\
\hline subtile & OK105 & Russia, Sakhalin & Pisarenko op03741 MHA & MZ417373 & \\
\hline
\end{tabular}

calculated after omitting the first $25 \%$ trees as burn-in. Analyses were performed on the Cipres Science Gateway (http://www.phylo.org/portal2) on XSEDE.

Maximum parsimony analysis was performed in Nona (Goloboff, 1994) in the Winclada shell (Nixon, 1999), with bootstrap calculations for 2000 replications ( $\mathrm{N}$ searches 100 , starting trees per rep 100, max trees 100, do max).

\section{RESULTS}

Both nuclear ITS and plastid markers place the Sakhalin specimen in the clade with two specimens of Arvernella microcalda from France, in the former with high support ( $\mathrm{PP}=1, \mathrm{BS}=95)$. The Arvernella-clade is placed in the basal grade within the Ablystegiaceae clade that includes the genera Platyhypnum, Myrinia, Campylophyllum, Tomentypnum, and Drepanium. In the ITS tree (Fig. 1) it is sister to clade of Campylophyllum montanum (= Hygrohypnum montanum), while in the $a t p \mathrm{~B}-r b c \mathrm{~L}$ tree (Fig. 2) it is a member of a clade with a polytomy of five groups: Avernella microclada+Sakhalin specimen, Campylophyllum halleri, C. montanum, Platyhypnum smithii, and P. cochlearifolium $+P$. norvegicum.

\section{DISCUSSION}

The results of the present find illustrate a still poor exploration of the family that needs additional efforts in many regions of the world. Small plants of a rather similar habit were for a long time classified in Amblystegiella (Podpera, 1954), while they are now placed in the genera Platydictya (fam. Plagiotheciaceae), Serpoleskea (Amblystegiaceae, close to Campylophyllopsis), and Pseudoamblystegium (Amblystegiaceae, close to Hygrohypnum).

Two independent phylogenetic analyses of nuclear and plastid markers indicate the placement of the Sakhalin plant in Arvernella, albeit with a moderate support in the less variable plastid $a t p \mathrm{~B}-r b c \mathrm{~L}$ marker. The systematic position inferred from the molecular phylogenetic analyses is congruent with plant morphology: the Sakhalin specimen has a lot in common with the French Arvernella, namely a very small plant size, leaf areolation and costa structure, as well as a well-developed peristome. However, the longer costa and almost smooth laminal cells in the Sakhalin plants versus distinctly prorate in A. microclada suggest the description of Sakhalin plant as a second species of the genus Arvernella.

\section{TAXONOMY}

Arvernella pisarenkoi Ignatov \& Ignatova

Type: Russia, Sakhalin Island, Tymovo Distr., Nabilsky Mt. Range, Chamginsky pass, creek - a tributary of

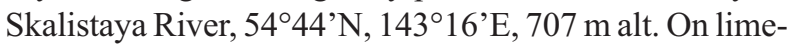
stone outcrops. 12 Sep 2009, coll. Pisarenko O.Yu. op03738 (holotype MHA!, isotypes NSK!, MW!).

Etymology: the species is described in honor of Olga Yu. Pisarenko, bryologist from the Central Siberian Botanical Garden (Novosibirsk), who studied the moss flora of Asian Russia and collected the type specimen of the described species.

Diagnosis: Arvernella pisarenkoi is similar to A. microclada in very small plant size, similar shape of leaves, and spore size, but differs in inclined to pendent capsules; slightly larger leaves, $0.27-0.40 \times 0.10-0.16 \mathrm{~mm}$ vs. 0.14 $0.35 \times 0.055-0.08 \mathrm{~mm}$ in $A$. microclada; shorter laminal cells, $9-15(-20) \times 5-6(-7) \mu \mathrm{m}$ vs. $17-22 \times 3-10 \mu \mathrm{m}$, a more distinct costa, which is absent or very short and indistinct in A. microclada; perichaetial leaves of $A$. pisarenkoi are also larger, $0.9-1.15 \mathrm{~mm}$ vs. $0.3-0.4 \mathrm{~mm}$ long.

Description. Plants minute, in moderately dense, tiny, delicate mats, green to dark green. Stems creeping, to 10 $\mathrm{mm}$ long, stem composed of homogeneous cells, without 


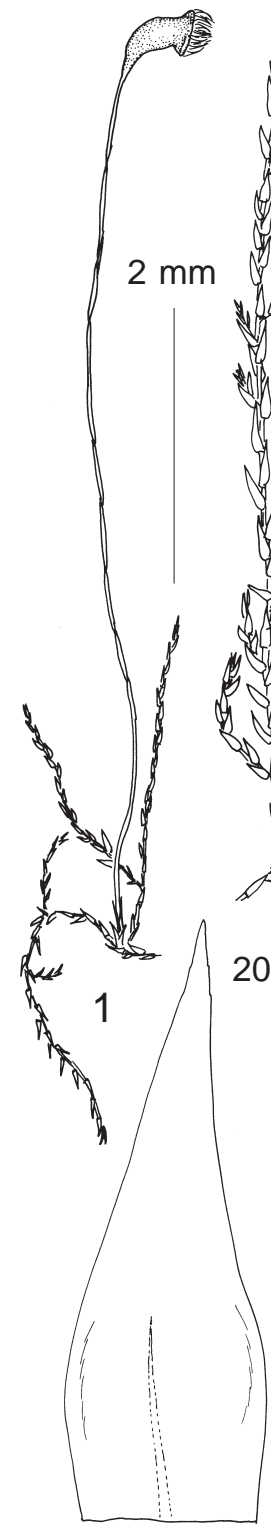

10
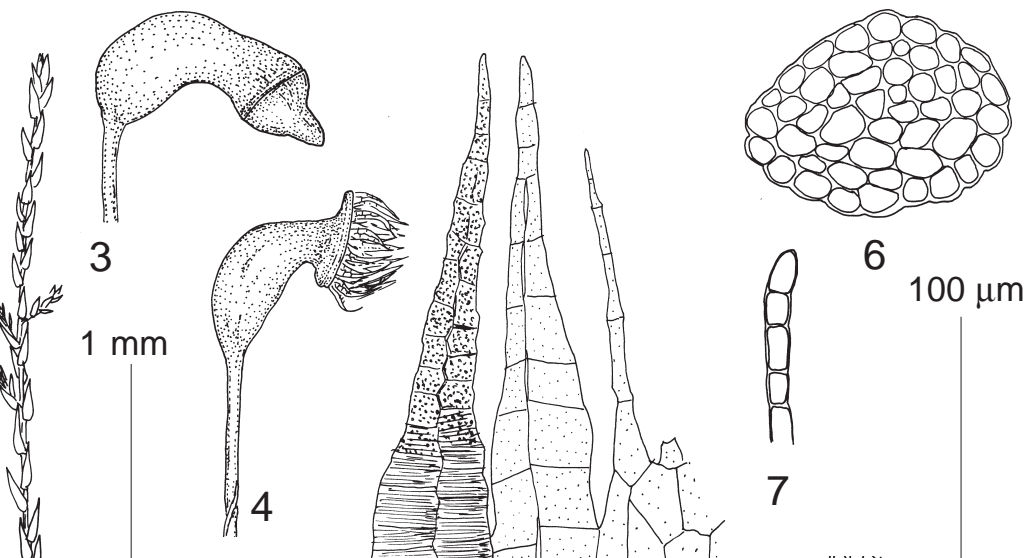

7

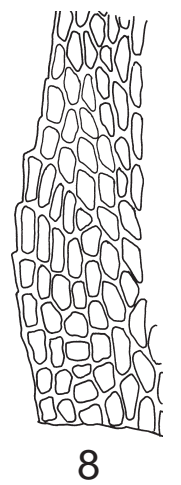

5
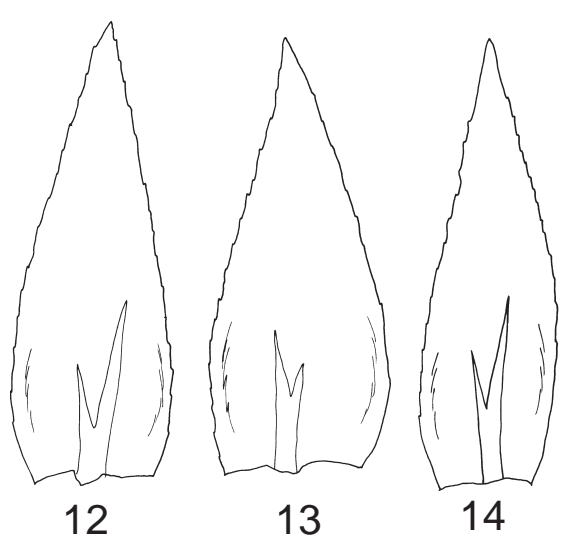

13

Fig. 3. Arvernella pisarenkoi Ignatov \& Ignatova (from: Russia, Sakhalin, 12.IX.2009 Pisarenko op03738, MHA): 1-2: habit, dry; 3-4: capsules; 5: peristome; 6: stem transverse section; 7: axillary hair; 8: basal leaf cells; 9: cell areolation of whole stem leaf; 10-11: perichaetial leaves; $12-16$ : stem leaves. Scale bars: $2 \mathrm{~mm}$ for $1 ; 1 \mathrm{~mm}$ for $2-4 ; 200 \mu \mathrm{m}$ for $10-16 ; 100 \mu \mathrm{m}$ for $5-9$.

central strand, epidermal cells with only slightly thicker walls than cells inwards, terete foliate, irregularly branched, branches diverging at about right angle, 2-4 $\mathrm{mm}$ long, terete foliate; rhizoids inserted below leaf insertion; axillary hairs 4-5-celled, upper cell ca. $20 \times 10$ $\mu \mathrm{m}$; paraphyllia absent; proximal branch leaves linear to lanceolate. Stem leaves appressed when dry, erect when moist, $0.27-0.40 \times 0.10-0.16 \mathrm{~mm}$, triangular-lanceolate, gradually narrowed to apex, not or very slightly narrowed to base, not or very shortly decurrent; costa forked, to $0.2-0.4$ the leaf length, indistinctly delimited; margins plane, obtusely serrulate throughout; laminal cells 9-15 $(-20) \times 5-6(-7) \mu \mathrm{m}$, with length to width ratio $2.0-2.5$ (-3.4):1, moderately thick-walled, smooth or weakly pro- rate; alar cells sub-quadrate to short-rectangular, 7-8 $\mu \mathrm{m}$ wide, forming indistinctly delimited group 5-7 cells long and 2-3 cells wide. Branch leaves somewhat smaller and narrower than stem leaves. Autoicous. Perigonia budlike, perigonial leaves ovate, strongly concave. Perichaetial leaves straight, $0.9-1.15 \times 0.4-0.5 \mathrm{~mm}$, triangularlanceolate, acuminate, eplicate, with thick, gradually tapered, indistinctly delimited costa to 0.6 the leaf length. Setae to $9 \mathrm{~mm}$, erect to somewhat flexuose, smooth, brownish to reddish-brown. Capsules inclined to somewhat pendent, urn $0.5-0.7 \times 0.2-0.3 \mathrm{~mm}$, elongate-ovoid, strongly contracted below mouth when dry and empty. Annuli deciduous. Opercula conic and shortly and broadly rostrate. Exostome teeth $260-300 \mu \mathrm{m}$ long, cross-stri- 

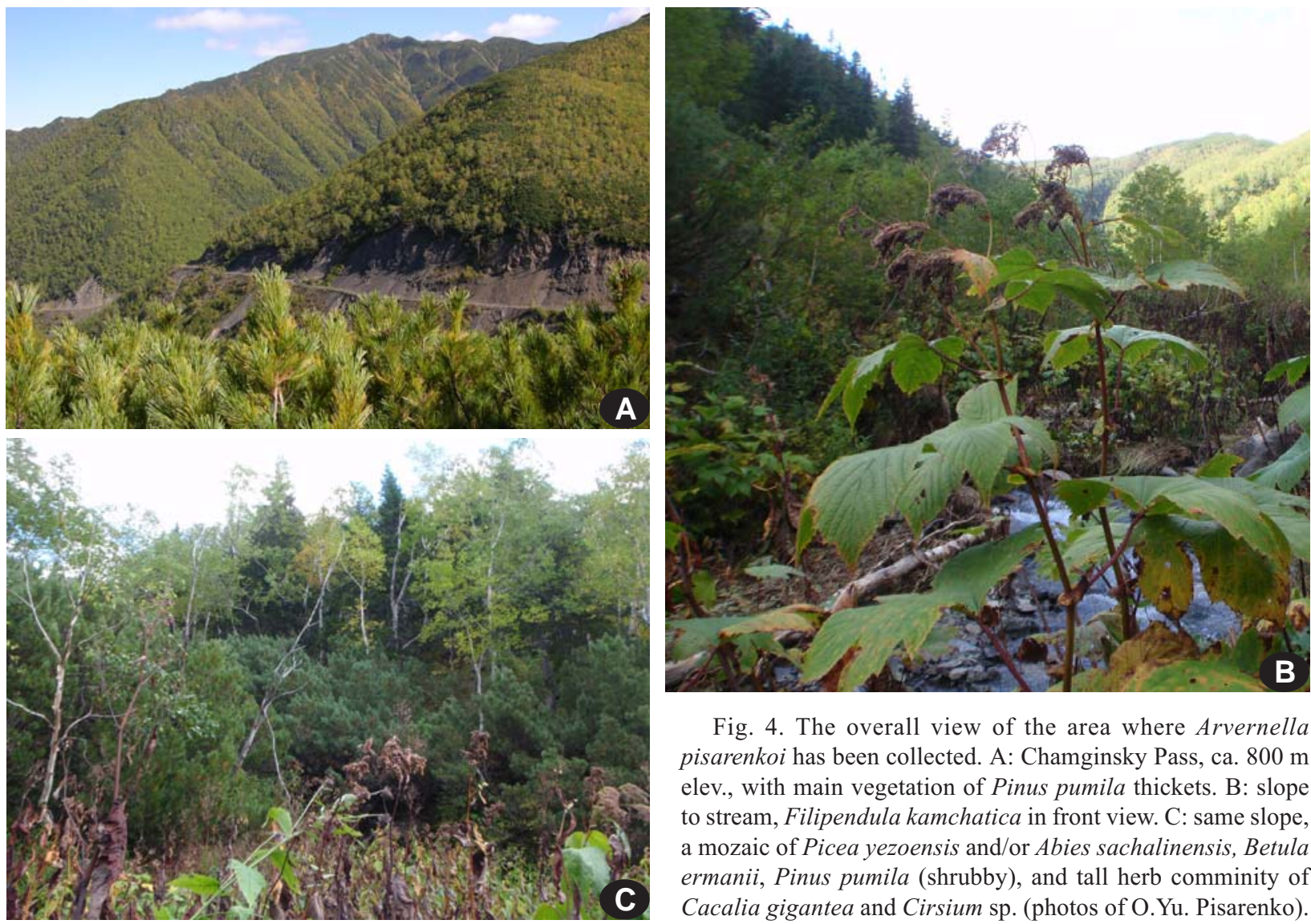

Fig. 4. The overall view of the area where Arvernella pisarenkoi has been collected. A: Chamginsky Pass, ca. $800 \mathrm{~m}$ elev., with main vegetation of Pinus pumila thickets. B: slope to stream, Filipendula kamchatica in front view. C: same slope, a mozaic of Picea yezoensis and/or Abies sachalinensis, Betula ermanii, Pinus pumila (shrubby), and tall herb comminity of Cacalia gigantea and Cirsium sp. (photos of O.Yu. Pisarenko).

olate below, papillose above; endostome with basal membrane ca. 1/2 of its length, segments narrow, about as long as exostome teeth, cilia 1-2, slightly shorter than segments, nodose. Spores 10-13 $\mu \mathrm{m}$.

Differentiation. Sterile plants of $A$. pisarenkoi could be confused with Serpoleskea confervoides, but they are smaller, with appressed leaves when dry, and also (1) the perichaetial leaves of $A$. pisarenkoi have a costa that is absent in Serpoleskea; (2) the stem is formed by homogeneous cells, whereas in Serpoleskea cells of two outer stem layers are markedly smaller than the inner cells.

Using the keys in Kanda (1975) and Noguchi et al. (1991), Sakhalin plants were previously identified as Platydictya fauriei Card. (the genus Platydictya was accepted in that treatment in its old sense, being almost equal to Amblystegiella) and published by Chedrantseva et al. (2018). However, Platydictya fauriei has linear-rhomboid cells $20-25 \times 3.5-5 \mu \mathrm{m}$ vs. $9-15(-20) \times 5-6(-7) \mu \mathrm{m}$ in A. pisarenkoi; upper leaf cells even longer, $20-28 \mu \mathrm{m}$ vs. not longer than mid-leaf cells; laminal cells smooth vs. somewhat prorate; alar cells somewhat enlarged and hyaline vs. not enlarged; perichaetial leaves oblong-lanceolate, $1.0 \times 0.3 \mathrm{~mm}$, plicate, without prominent costa vs. ovate, $0.90-1.15 \times 0.4-0.5 \mathrm{~mm}$, eplicate, with prominent costa; spores $12-15$ vs. $10-13 \mu \mathrm{m}$.

Ecology. According to Pisarenko field notes (letter of 4 June 2021), the collection was done on a small outcrop (not shown, more exact loc. data from map $50.73356^{\circ} \mathrm{N}$, $143.26138^{\circ} \mathrm{E}$ ) on a slope to small stream valley in the mixed forest (Fig. 4B,C). The forest with tall trees of Picea yezoensis and Abies sachalinensis grow in this area only in sheltered valleys, while more exposed slopes are covered by Betula ermanii s.l. and Alnus fruticosa crooked forest (Fig. 4A) and Pinus pumila tickets (shrubby pine, Fig. 4A, C). Forest is usually intermingled with tall-herb communities with Filipendula kamchatica, species of $\mathrm{Ca}$ calia, Angelica, and Senecio).

Collection from that outcrops and nearby (including stream, forest floor and more exposed rocks) include: Amphidium lapponicum, Bartramiopsis lescurii, Brachythecium baicalense, B. cirrosum, Codriophorus corrugatus, Cyrtomnium hymenophylloides, Dilutineuron brevisetum, Eurhynchiastrum pulchellum, Fissidens dubius, Gymnostomum aeruginosum, Homalia trichomanoides, Hygrohypnella ochracea, Isopterygiella pulchella, Lescuraea incurvata, L. patens, L. radicosa, L. saxicola, Mnium thomsonii, Myurella julacea, Niphotrichum canescens, Platyhypnum cochlearifolium, P. duriusculum, Oxystegus tenuirostris, Plagiomnium medium, Plagiothecium cavifolium, P. denticulatum, P. nemorale, Pleurozium schreberi, Pogonatum contortum, Pohlia cruda, Rhynchostegium aquaticum, Saelania glaucescens, Schistidium lancifolium, S. rivulare, and Sciuro-hypnum plumosum. 
The environments of the Sakhalin locality are in many aspects similar to those of Arvernella microcalda habitats in France (Hugonnot, pers. comm.), where it grows also at the elevation at about timberline, at transition of Fagus forest to tall-herb meadows with Cacalia, Cicerbita, Rumex, etc. Associated moss species include, among others, Oxystegus tenuirostris and Lescuraea patens, the latter being quite rare in Russia (Hugonnot \& Hedenäs, 2015).

\section{ACKNOWLEDGEMENS}

We are grateful for critical comments to Vincent Huggonot and to Lars Hedenäs, who also did linguistic corrections, to Olga Pisarenko for photos, locality description and making her specimens available for study. The molecular study of OK was supported by RSF 18-1400121, work on specimens by MI was conducted in the course of institutional project 19-119012390082-6, and EI acknowledges MSU institutional project AAAA-A16116021660039-1. We thank Ministry of Higher Education and Science of Russian Federation for the support the Center of Collective Use "Herbarium MBG RAS", grant 075-15-2021-678.

\section{LITERATURE CITED}

BOULAY, J.N. 1884. Muscinées de la France, Première Partie: Mousses. - Paris, F. Savy, clxxiv + 624 pp

CHERDANTSEVA, V.YA, O.YU. PISARENKO, M.S. IGNATOV, E.A. IGNATOVA, V.E. FEDOSOV, S.V. DUDOV \& V.A. BAKALIN. 2018. Mosses of the southern Russian Far East, an annotated checklist. - Botanica Pacifica 7(2): 1-22.

CORLEY, M.F.V., A.C. CRUNDWELL, R.P.G. DÜLL, M.O. HILL \& A.J.E. SMITH. 1981 [1982]. Mosses of Europe and the Azores: an annotated list of species, with synonyms from the recent literature.Journal of Bryology 11: 609-689.

FREY, W. \& M. STECH. 2009. Bryophyta (Musci, mosses). - In: Frey, W. (ed.). Syllabus of plant families A. Engler's Syllabus der Pflanzenfamilien. Part 3. Bryophytes and seedless vascular plants. 13th ed. Gebr. Borntraeger Verlagsbuchhandlung, Stuttgart, Germany: 116-257.

GARDINER, A., M. IGNATOV, S. HUTTUNEN \& A. TROITSKY. 2005. On resurrection of the families Pseudoleskeaceae Schimp. and Pylaisiaceae Schimp. (Musci, Hypnales). - Taxon 54: 651-663.

GOFFINET, B., W.R. BUCK \& A.J. SHAW. 2009. Morphology, anatomy, and classification of the Bryophyta. - In: Goffinet, B. \& A.J. Shaw (eds.). Bryophyte biology, 2nd edn. Cambridge: Cambridge University Press: 55-138.

GOLOBOFF, P.A. 1994. NONA: A Tree Searching Program. - Tucumán Argentina: Program and documentation, published by the author.

HODGETTS, N.G., L. SÖDERSTRÖM, T.L. BLOCKEEL, S. CASPARI, M.S. IGNATOV, N.A. KONSTANTINOVA, N. LOCKHART, B. PAPP, C. SCHRÖCK, M. SIM-SIM, D. BELL, N.E. BELL, H.H. BLOM,
M.A. BRUGGEMAN-NANNENGA, M. BRUGUÉS, J. ENROTH, K.I. FLATBERG, R. GARILLETI, L. HEDENÄS, D.T. HOLYOAK, V. HUGONNOT, I.U. KARIYAWASAM, H. KÖCKINGER, J. KUČERA, F. LARA \& R.D. PORLEY. 2020. An annotated checklist of bryophytes of Europe, Macaronesia and Cyprus. - Journal of Bryology 42(1): 1-116.

HUGONNOT, V. \& L. HEDENÄS. 2015. Arvernella microclada Hugonnot \& Hedenäs (Amblystegiaceae), a new minute species from France, requiring a separate genus. - Journal of Bryology 37(3): 184-191.

HUSNOT, P. T. 1884-1894. Muscologia Gallica. 2 vols. - Caen/Paris, T. Husnot/F. Savy, 458 pp.

HUTTUNEN, S., N. BELL, V.K. BOBROVA, V. BUCHBENDER, W.R. BUCK, C.J. COX, B. GOFFINET, L. HEDENÄS, B.-C. HO, M.S. IGNATOV, M. KRUG, O.I. KUZNETSOVA, I.A. MILYUTINA, A.E. NEWTON, S. OLSSON, L. POKORNY MONTERO, A.J. SHAW, M. STECH, A.V. TROITSKY, A. VANDERPOORTEN \& D. QUANDT. 2012. Disentangling knots of rapid evolution: origin and diversification of the moss order Hypnales. - Journal of Bryology 34(3): 187-211.

IGNATOV, M., A. GARDINER, V. BOBROVA, I. MILYUTINA, S. HUTTUNEN \& A. TROITSKY. 2007. On relationships of mosses of the order Hypnales, with the special reference to taxa traditionally classified in Leskeaceae. - In: Newton, A.E. \& R. Tangney (eds.), Pleurocarpous mosses: systematics and evolution. CRC Press, Boca Raton-London-New York: 177-213.

KANDA, H. 1975. A revision of the family Amblystegiaceae of Japan I. Journal of Science of the Hiroshima University, Series B, Division 2 (Botany) 15: 201-276.

KATOH, K. \& D.N. STANDLEY. 2013. MAFFT Multiple sequence alignment software version 7 : improvements in performance and usability. Molecular Biology and Evolution 30 (4): 772-780.

KUČERA, J., O.I. KUZNETSOVA, A. MANUKJANOVÁ \& M.S. IGNATOV. 2019. A phylogenetic revision of the genus Hypnum: towards completion. - Taxon 68(4): 628-660.

NIXON, K.C. 1999. Winclada (BETA) ver. 0.9.9. Available from: http:// www.cladistics.com/about winc.html

NOGUCHI, A., Z. IWATSUKI \& T. YAMAGUCHI. 1991. Illustrated Moss Flora of Japan. Vol. 4. - Nichinan, Hattori Botanical Laboratory: 743-1012.

PODPERA, J. 1954. Conspectus Muscorum Europaeorum. - Prague, Ceskoslovenské Akademie Ved, 697 pp.

RAMBAUT, A. \& A.J. DRUMMOND. 2007. Tracer v1.4. Available from http://beast.bio.ed.ac.uk/Tracer.

RONQUIST, F, M. TESLENKO, P. MARK, Van der, D.L. AYRES, A. DARLING, S. HÖHNA, B. LARGET, L. LIU, M.A. SUCHARD \& J.P. HUELSENBECK. 2012. MrBayes 3.2: efficient Bayesian phylogenetic inference and model choice across a large model space. - Systematic Biology 61: 539-542.

VANDERPOORTEN, A., L. HEDENÄS, C. J. COX \& A. J. SHAW. 2002. Circumscription, classification, and taxonomy of Amblystegiaceae (Bryopsida) inferred from nuclear and chloroplast DNA sequence data and morphology. - Taxon 51: 115-122.

Received 10 May 202

Accepted 6 August 2021 